\title{
A new species of Brasilonema (Scytonemataceae, Cyanoprokaryota) from Tolantongo, Hidalgo, Central Mexico
}

\author{
Itzel Becerra-AbSalón ${ }^{1 *}$, Beatriz Rodarte ${ }^{2}$, Karina Osorio ${ }^{1}$, Luisa Alba-Lois ${ }^{2}$, \\ Claudia SEgAL-KISChINEvZKY ${ }^{2} \&$ Gustavo MonTEJAno ${ }^{1 *}$
}

\author{
${ }^{1}$ Departamento de Biología Comparada, Universidad Nacional Autónoma de México (UNAM). Coyoacán, Código \\ Postal 04510, P.O. Box 70-474, México, Distrito Federal (D.F.), México; * Corresponding author e-mail: iba@, \\ ciencias.unam.mx,gmz@ciencias.unam.mx \\ ${ }^{2}$ Biología Celular, Facultad de Ciencias, UNAM, México D.F., México
}

\begin{abstract}
New approaches in taxonomy and the introduction of molecular tools have substantially changed the taxonomy of cyanobacteria, leading to new genera and species being defined based on genetic and morphological investigations. In addition, molecular tools have confirmed several previously defined cyanobacteria genera, including some based on morphological and ecological features. Several of them have also been split into new generic entities, such as Brasilonema. In the central region of Mexico, several populations have been identified to share some traits with this new genus. In the region of Tolantongo, Hidalgo (Hgo), we found cyanobacteria populations that correspond to Brasilonema description (FIORE et al. 2007), however the development of trichomes and hormogonia did not agree with the diagnosis of Brasilonema. We describe and analyze the cyanobacteria populations that we found in Tolantongo, and compare their features with the diagnostic generic features and those of several Brasilonema species. The results of morphological analyses were tested using molecular phylogenetic data derived from 16S RNA gene sequencing and the use of marker $c p c B A-\mathrm{IGS}$ for phycocyanin operon. From our analyses we conclude that the strain from Tolantongo belongs to the genus Brasilonema, and the differences observed are sufficient to propose a new species.
\end{abstract}

Key words: Brasilonema, cyanobacteria, life cycle, molecular phylogenetic, new species, phenotypic analyses, systematic

\section{Introduction}

Cyanobacterial taxonomy has changed considerably during the last few decades, due to the study of this group in previously uninvestigated regions and the introduction of modern tools in physiology, biochemistry, ecology and more recently the application of molecular methods (RAJANIEMI et al. 2005; KoMÁREK 2006, 2010). This resulted in numerous modifications to cyanobacterial taxonomy (CASTENHOLZ 2001; GugGer et al. 2002; GugGer \& Hoffmann 2004; HrouzeK et al. 2005; Willame et al. 2006; KOMÁREK 2010). In this way numerous new genera and species have been defined (ABED et al. 2002; Flechtner et al. 2002; CASAMATta et al. 2006; KomÁreK 2010; VACCARINo \& JoHANSEN 2011), some genera resulting from splitting, others have been confirmed (KoMÁrek 2010).
The classification of several genera into families has changed and will continue changing as their diagnostic characteristics are being re-evaluated (FleChtNer et al. 2002; KOMÁreK 2010).

We agree with the approach of the species concept proposed by KOMÁREK (2003a), which says that genetically stable and morphologically recognizable populations exist in nature and that these populations represent discontinuities which we could refer to as species. We also agree that the appropriate way to study them is correlating morphological, molecular and ecological features (KoMÁreK 2011), and this is our methodological approach in this paper.

The family Scytonemataceae Frank (order Nostocales Hoffmann, KomÁrek et KašTovskÝ) has been defined on the presence of Scytonematype false branching and isopolar trichomes. Scytonema Agardh ex Bornet et Flahault, 
Scytonematopsis Kiseleva, Kyrtuthrix ERCEgović and Petalonema Berkeley ex CoRrens were the genera traditionally included in this family (KomÁrek \& Anagnostidis 1989). Recently Fiore and collaborators (2007), using morphological and molecular evidence, defined a new genus within the family Scytonemataceae named Brasilonema FIORE et al. (2007).

Morphologically Brasilonema has macroscopic growths, development comprised of densely packed fascicles, isopolar filaments, rare false branching, rounded unattenuated apical cells, and isopolar hormogonial development (FIORE et al. 2007). Currently, seven species are included in Brasilonema (Fiore et al. 2007; Aguiar et al. 2008; SANT' AnNa et al. 2011). Six were described from Brazil: B. bromeliae (Fiore et al. 2007), $B$. octagenarum (Aguiar et al. 2008), B. epidendron, $B$. ornatum, B. terrestre and B. sennae (SANT' AnNA et al. 2011). B. sennae was first described as Camptylonemopsis sennae (КоMÁreK 2003b) but later was reclassified as Brasilonema (AguiAR et al. 2008; SANT' ANNA 2011). Whereas Brasilonema roberti-lamii, originally described in the Antilles as Tolypothrix roberti-lamii (BOURRELLY \& MANGUiN 1952), was later added to the genus Shmidleinema by KOMÁreK (1989) and recently moved to Brasilonema (SANT' ANNA et al. 2011).

During our floristic studies on cyanobacteria in the central region of Mexico, we found several populations showing certain Brasilonema's characteristics. Nevertheless these populations showed trichome and hormogonial structures among other characteristics that distinguish it from the Brasilonema species described. For this reason we decided to investigate these populations more thoroughly so as to assign them to the appropriate genus with greater certainty.

Analyzing the morphological and phylogenetic properties using $16 \mathrm{~S}$ rRNA and the $c p c \mathrm{BA}-$ IGS phycocyanin region described in this paper, we conclude that the populations indeed belong to Brasilonema. Furthermore we consider that the variations observed in our populations indicate that they should be considered as new species.

\section{Materials and Methods}

Studied area and sample collection. Our investigation took place in Tolantongo - a valley at the end of a ravine in the municipality of Cardonal, in Hidalgo state, Mexico. This locality has a diverse mineral content and travertine springs with varying temperatures (about 20 $-40^{\circ} \mathrm{C}$ ); It is located at $20^{\circ} 38^{\prime} 38.3^{\prime \prime} \mathrm{N}$ and $98^{\circ} 59^{\prime} 34^{\prime \prime}$ $\mathrm{W}$, and $1422 \mathrm{~m}$ above sea level.

Cyanobacteria populations were found inhabiting on wet limestone walls near runoffs within a system of waterfalls (Fig.1a). Where temperature ranged from $30-32{ }^{\circ} \mathrm{C}, \mathrm{pH} \mathrm{7.4}$, conductivity was $984-1011$ $\mu \mathrm{S} . \mathrm{cm}^{-1}$, and radiance was $45-424.5 \mu \mathrm{mol}^{-1} \cdot \mathrm{m}^{-2}$.

We collected samples for two types of preparation: 1) herbaria samples fixed with $4 \%$ formaldehyde and 2) live samples transported on ice. We recorded the environment luminosity, temperature and $\mathrm{pH}$.

Morphological characterization and cultures. Morphological variability and life cycles were studied on live material (fresh and cultured), and on $4 \%$ formaldehyde fixed material. We observed the samples using an Olympus BX51 microscope with DIC equipped with an Olympus DP-12 digital camera. Morphological characterizations were made according to the classification scheme proposed by KOMÁREK (2010) and the descriptions of FIORE et al. (2007), Aguiar et al. (2008), SAnt' AnNa et al. (2011). Montejano et al. (2010), and Rodarte et al.(unpublished).

We isolated filaments from live material to establish monoclonal cultures in BG11 media, with and without a nitrogen source, both in solid and liquid media (ALLEN 1968). Cultures were grown in a Sanyo chamber in a controlled environment at $25{ }^{\circ} \mathrm{C}, 37.3 \mathrm{mmol}$. $\mathrm{cm}^{-2} \cdot \mathrm{s}^{-1}$ irradiance and a $12: 12 \mathrm{~h}$ light-dark cycle. Due to environmental variations of temperatures in Tolantongo, we had to choose the temperature at which most cultures grew well $\left(25^{\circ} \mathrm{C}\right)$. Although it was not the ideal temperature for culturing our populations like Brasilonema, we found no significant morphological changes.

DNA isolation and PCR amplification. DNA was extracted from monoclonal cultures by freezethawed sample 5 cycles as described by PALINSKA and coworkers (2006), followed by the mechanical rupture of the sample using a pestle. We completed the extraction using an UltraClean Microbial DNA Isolation Kit (MO-BIO Labs, Carlsbad, CA, USA).

PCR amplification of the 16S RNA ribosomal gene was performed using the primers $106 \mathrm{~F}$ (NüBEL et al. 1997) and 1494Rc (NeILAN et al. 1997); the cpcBA-IGS region was amplified using primers reported by NEILAN and colleagues (1995). The amplification reaction was performed using $\mathrm{MgCl}_{2}$ buffer $(1 \times 2.5 \mathrm{mM}), 10 \mathrm{mM}$ solution of dNTP's, $0.5 \mu \mathrm{M}$ of each oligonucleotide and $1 \mathrm{U}$ of DNA polymerase (Amplificasa, Biogénica Mexico City, Mexico). Both amplification reactions were conducted as follows: one denaturation cycle at $94{ }^{\circ} \mathrm{C}$ for $7 \mathrm{~min}$; 30 cycles of denaturation at $94{ }^{\circ} \mathrm{C}$ for $30 \mathrm{sec}$, annealing at $63^{\circ} \mathrm{C}$ for $1 \mathrm{~min}$ and an extension at 
$72{ }^{\circ} \mathrm{C}$ for $1 \mathrm{~min}$; final extension at $72^{\circ} \mathrm{C}$ for $7 \mathrm{~min}$. The amplification products were purified with a GeneClean III Kit (Bio 101 Systems, La Jolla, CA, USA) and submitted for bidirectional sequencing to the Instituto de Biología, UNAM. Fragments were assembled using the software Bioedit version 7.0.9.0 (HALL 1999).

Alignment and phylogenetic analysis. Phylogenetic analysis was based on two sequences of DNA, 16S rRNA gene (bp106-1494), and cpcBA-IGS region of the phycocyanin gene. The taxa used in 16S rRNA and $c p c \mathrm{BA}$ sequences analyses included a total of 43 and 25 OTUs respectively, both with one novel sequences from Tolantongo Hgo, México and OTUs from GenBank.

We made a BLAST search to select more related sequences with the Tolantongo sequence. We also selected sequences based on morphological classification criteria, so we could include sequences from all the Nostocalean families: Scytonemataceae, Microchaetaceae, Nostocaceae, Rivulariaceae, Symphyonemataceae, Hapalosiphonaceae and Stigonemataceae. In both analyses the external group was Gloeobacter violaceaus. The sequences were aligned using Clustal W (Higgins et al. 1994). Gaps were coded for missing information.

The trees were constructed using parsimony and maximum likelihood analyses in TNT (GoLOBOFF et al. 2008) and Mega version 5 (TAMURA et al. 2011) programs, respectively. Parsimony analyses were performed using a heuristic search combining sectorial, ratchet, drift and tree fusing methods with 10 addition sequences; all trees generated were retained. Bootstrapped of 500 replicates was used. The non-informative matrix data were eliminated with WinClada (NiXON 2002).

The best models for analysis with maximum likelihood were found with Mega version 5 (TAMURA et al. 2011). Maximum likelihood was performed using the Kimura 2 -parameter with gamma distribution and sites evolutionarily invariable to $16 \mathrm{~S}$ rRNA and Tamura 3 - parameter with gamma distribution to cpcBA-IGS analysis. Bootstrapping was conducted with 500 replicates.

\section{Results}

\section{Taxonomic observations}

\section{Brasilonema tolantongensis BECERRA-ABSALÓN et Montejano sp. nov.}

Thallus macroscopic, blackish-violet mats, densely fasciculated and prostrate on substrate. Mature filaments isopolar, cylindrical, 17.5 - 24.5 $\mu \mathrm{m}$ wide $(\overline{\mathrm{x}}=21 \mu \mathrm{m})$, closed at rounded ends, open after hormogonia are released. Sheaths thin, not lamellated when young, slightly lamellated with age, colorless. Mature trichomes $12.5-20$ $\mu \mathrm{m}$ wide $(\overline{\mathrm{x}}=7 \mu \mathrm{m})$, not attenuated, not or slightly constricted, generally of same width along the whole length, becoming wider at the ends when forming hormogonia; sometimes calyptras are found in apical cells. Young trichomes attenuated in single or both ends. False branching rare, predominantly double, although sometimes single, or in some filaments growing from an attached hormogonium. Cells violet to brown, variable in length, shortest in hormogonia, apical cells and meristematic zones; longer in older parts, $5.25-18.7 \mu \mathrm{m}$ in length $(\bar{x}=11.4 \mu \mathrm{m})$, with granular content mainly in older cells; vacuolelike structures were found in rows of neighboring cells. Heterocytes solitary, intercalar, discoidal to rectangular, wider than long in trichomes $12.48-$ $16.4 \mu \mathrm{m}$ wide $(\overline{\mathrm{x}}=14.85 \mu \mathrm{m})$ by $7.4-15.6 \mu \mathrm{m}$ long $(\overline{\mathrm{x}}=9.6 \mu \mathrm{m})$; solitary, basal, hemispherical in hormogonia. Hormogonia with asymmetrical growth becoming heteropolar, wider than trichomes $16.2-41.5 \mu \mathrm{m}$ wide $(\overline{\mathrm{x}}=23 \mu \mathrm{m})$.

Habitat: Populations from Tolantongo,in subtropical, subaerophytic environments, on wet limestone walls near runoffs (Fig. 1a) where temperatures range from $30-32{ }^{\circ} \mathrm{C}, \mathrm{pH} 7.4$, conductivity $984-1011 \mu \mathrm{S} . \mathrm{cm}^{-1}$, and iradiance $45-424.5 \mu \mathrm{mol}^{-1} \cdot \mathrm{m}^{-2}$.

Iconotype: Fig. 2.

Type locality: Tolantongo in the state of Hidalgo, México.

The populations studied shared the following characteristics with the genus Brasilonema: 1) a subaerophytic habitat, attached to solid substrates (Fig. 1 a); 2) macroscopic thallus comprised of densely packed fascicles; 3) mature filaments end rounded, remaining closed until hormogonia were released (Figs $1 \mathrm{~b}-\mathrm{c}, 2 \mathrm{a}-\mathrm{c}$ ); 4) calyptra occasionally observed (Figs 1 b, 2 a); 5). Solitary, discoidal to cylindrical, intercalary heterocytes in mature trichomes were identified (Figs 1 b, 2 a); 6) Vacuole - like structures and granulation in the cells (Figs 1 b, 2 a); 7) false branching, single and double (Figs $1 \mathrm{~d}, 2 \mathrm{~b}$ ).

On the other hand, populations from Tolantongo differed from the genus Brasilonema in that: 1) mature filaments lost their isopolarity temporarily when hormogonia were formed (Figs $1 \mathrm{c}, 2 \mathrm{c}$ ); 2) hormogonia were observed to be heteropolar, with one basal heterocyte, while the other end was attenuated (Figs $1 \mathrm{f}, 2 \mathrm{~d}$ ); 3) hormogonia had asymmetrical growth, such that 

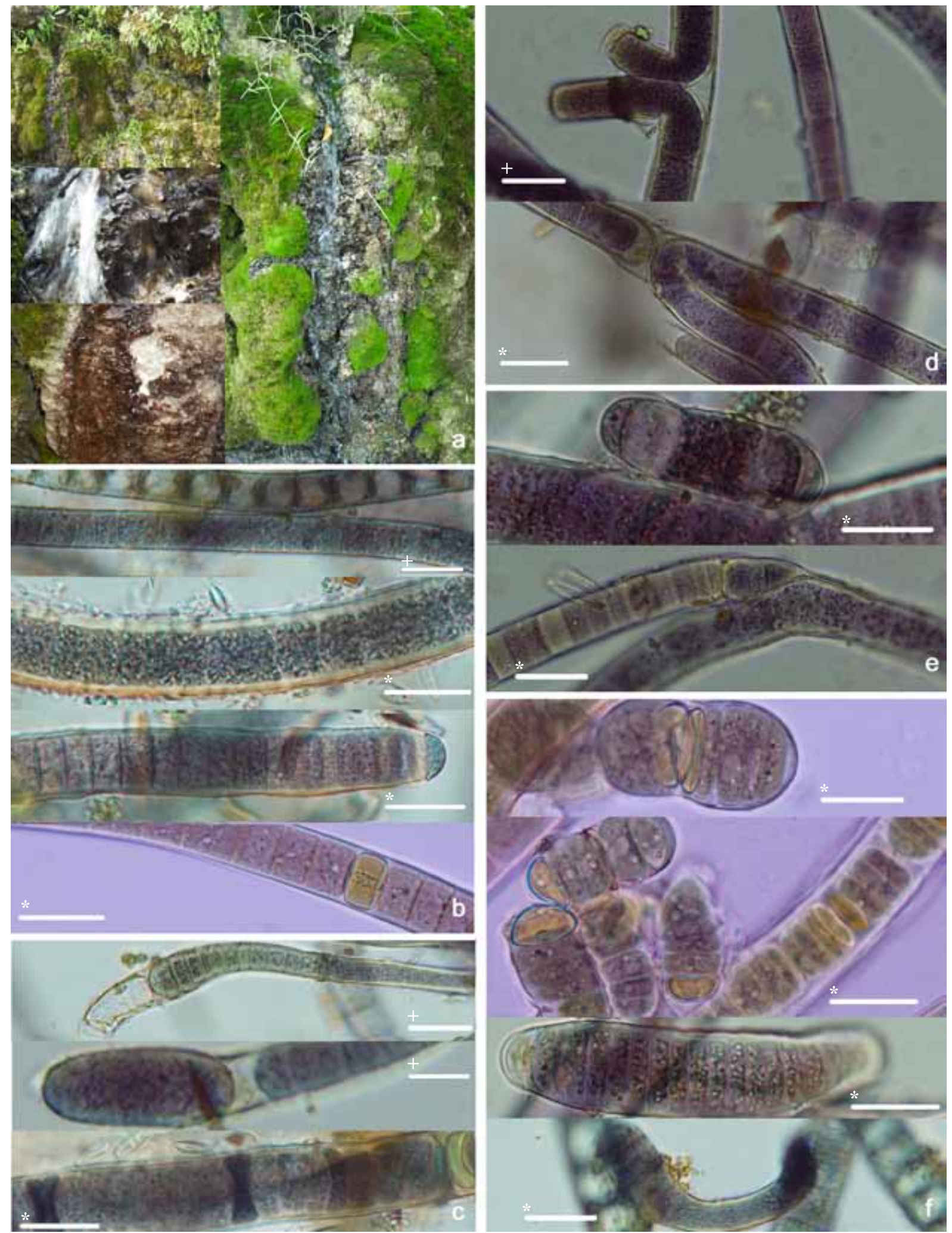

Fig. 1. Primary characteristics of Brasilonema tolantongensis: (a) habitat and type of thallus; (b) mature filaments features (from top to bottom: vacuole-like structures, granulation, calyptra, and heterocyte); (c) hormogonia formation (from top to bottom: widening of apical cells, hormogonia wider than trichomes, necridic cells); (d) false branching (top, double branching and bottom, single branching); (e) branch formed from hormogonia; (f) hormogonia development (from top to bottom: basal heterocyte formation; initial asymmetric division and young trichomes with attenuation at one of the apical cells, and characteristic letter "J" shape). Scale bar $20 \mu \mathrm{m}(+), 30 \mu \mathrm{m}(*)$. 


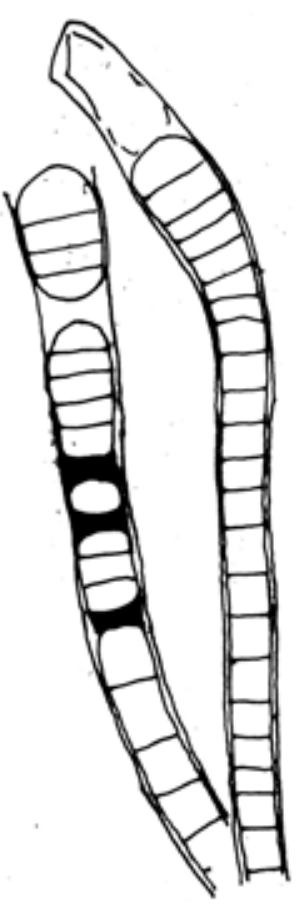

c

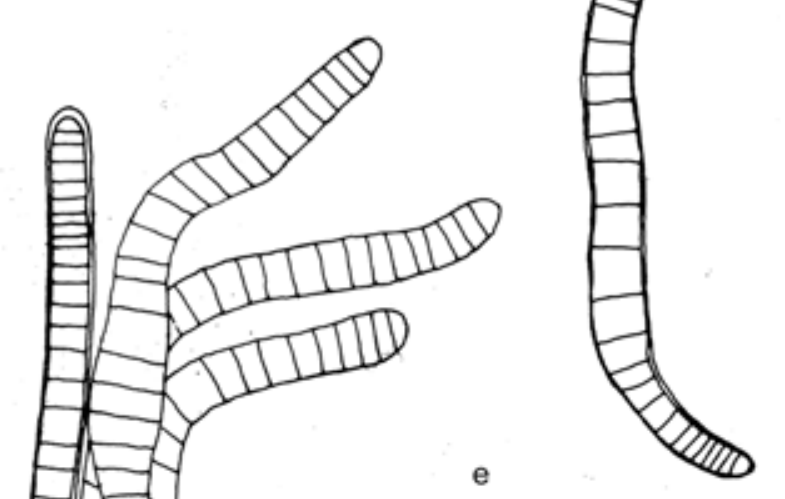

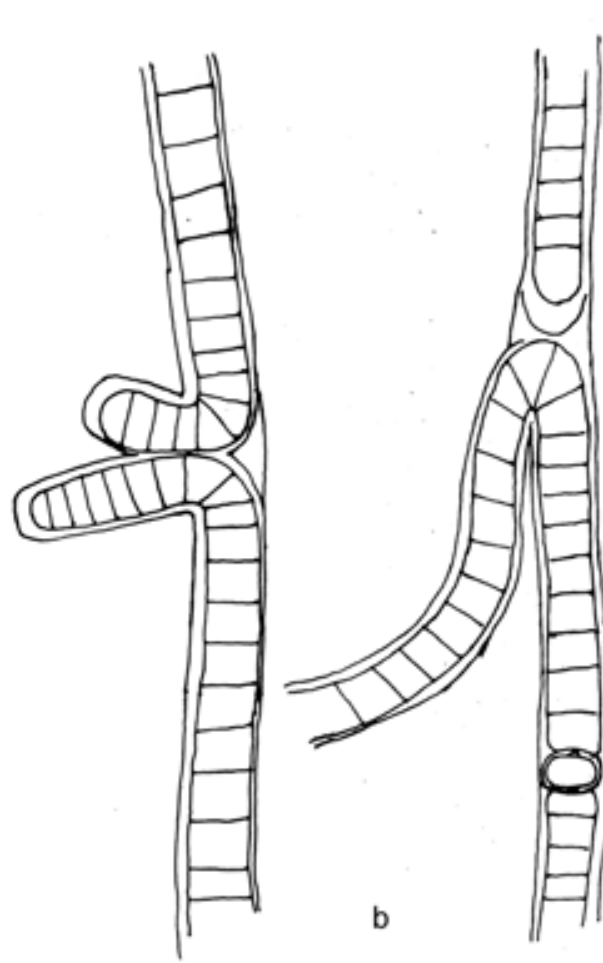
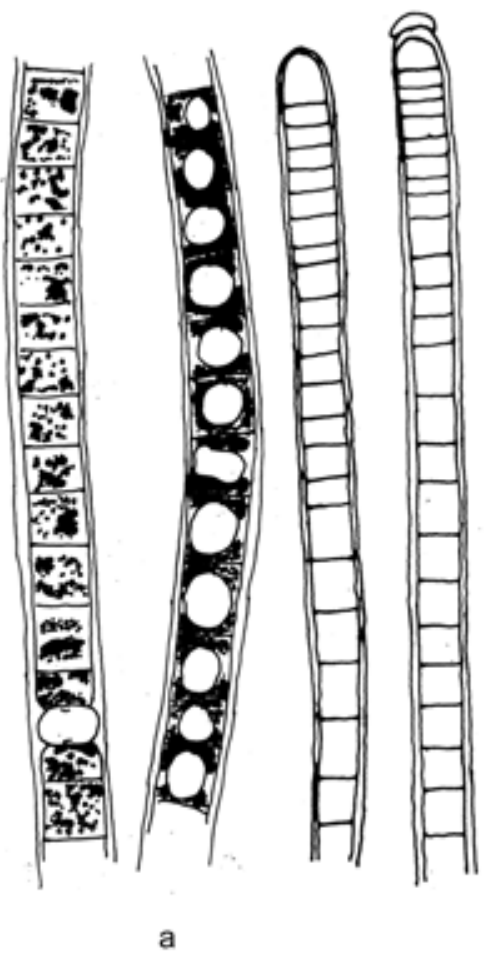

a
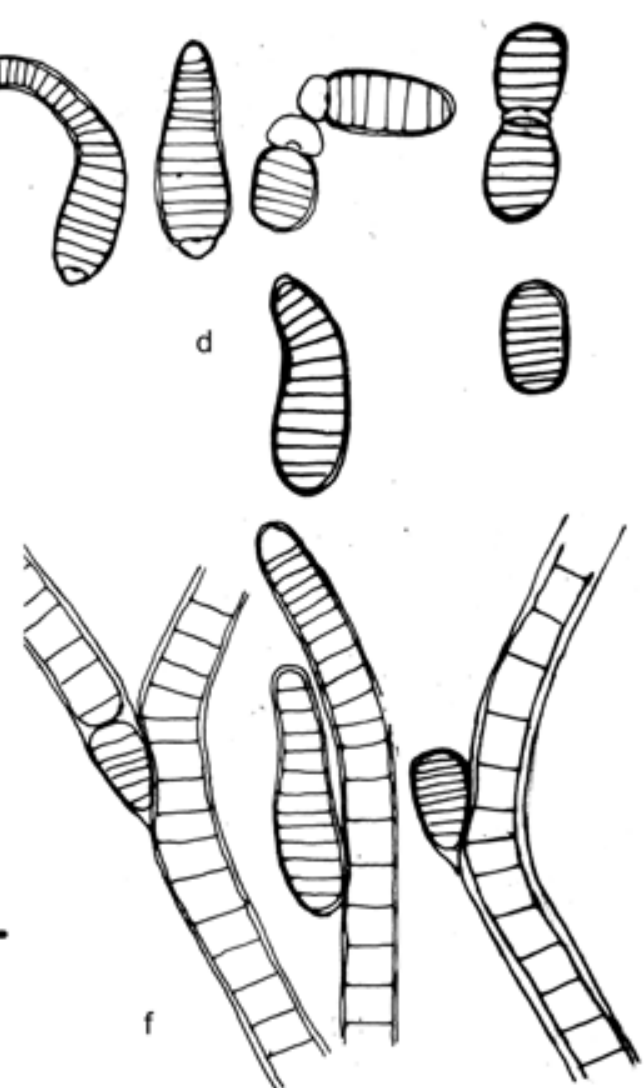

Fig. 2. Drawing of Brasilonema tolantongensis (Iconotype): (a) mature trichomes; (b) false branching; (c) hormogonia formation; (d) hormogonia development and germination; (e) young trichomes development; (f) formation of false branching initiating from one hormogonium. Scale bar $20 \mu \mathrm{m}$. 


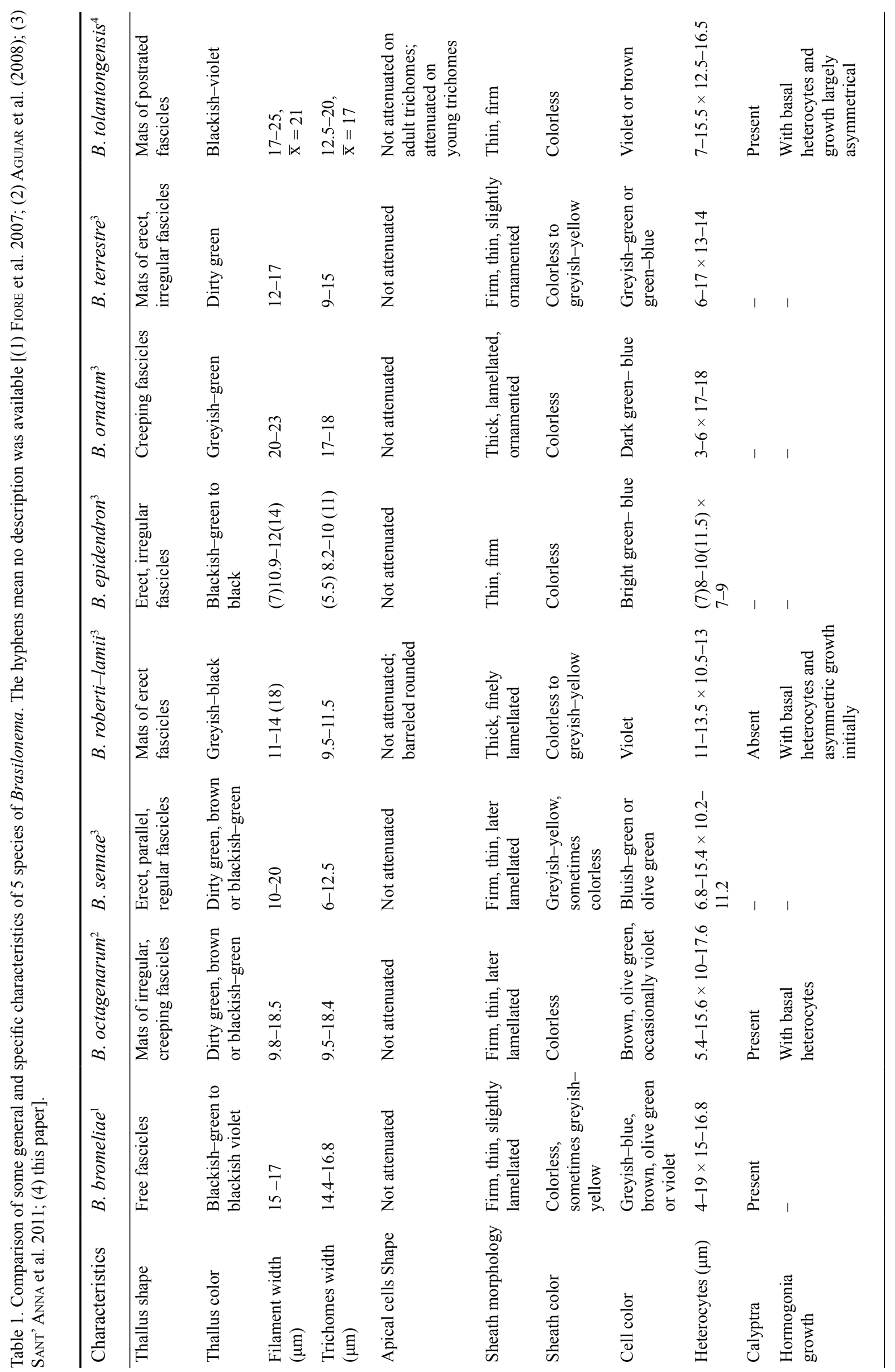


growth began at one end (Figs $1 \mathrm{f}, 2 \mathrm{~d}$ ); 4) young filaments had attenuated apical cells (Figs 1 f, 2 e).

A comparison of characteristics used to determine the species of the genus Brasilonema are shown in Table 1. We analyzed all species of Brasilonema, and the strains from Tolantongo. There are several features that distinguish the populations studied from those of species previously assigned to this genus: 1) filaments and mature trichomes were wider (Table 1); 2) hormogonia were wider than trichomes (Figs 1 c, 2 c); 3) hormogonia and young trichomes had asymmetric growth (Figs 1 f, 2 d); 4) apical cells on hormogonia and young trichomes were attenuated and when a basal heterocyte was observed, only the end opposite to the heterocyte was attenuated (Figs $1 \mathrm{f}, 2 \mathrm{~d}-\mathrm{e}$ ).

\section{Life cycle observations}

In mature trichomes, meristematic zones were found on apical cells. Apical cells were rounded and sometimes formed calyptras (Figs 1 b, 2 a, e). Cell content was highly granular on the oldest parts of filaments, found at the center (Fig. $1 \mathrm{~b}$ ).

Hormogonia were formed by fragmentation, generally only at one end of the filament, and almost always by necridic cells. Prior to their release, hormogonia attained a greater width than trichomes (Figs $1 \mathrm{c}, 2 \mathrm{c}$ ) making filaments heteropolar in this stage of their life cycle. When hormogonia were released, they almost always formed a basal heterocyte (Figs $1 \mathrm{f}, 2 \mathrm{~d}$ ). In culture, we observed that the basal heterocyte of hormogonia could form one or two intercalary heterocytes, followed by fragmentation of heterocytes (Figs $1 \mathrm{f}, 2 \mathrm{~d}$ ).

Meristematic zones of hormogonia were observed at the apical cells, which became attenuated as the cells divided. Cell division initiated growth of hormogonia at one end, particularly in the presence of a basal heterocyte. This asymmetric growth continued until heteropolar young trichomes were formed. Later, the opposite end started to divide and became attenuated causing the middle portion to appear wider than the ends (resembling worms). In the final stages, cells reached normal width and trichomes became isopolar, with the same width throughout the length of the trichome (Figs $1 \mathrm{f}, 2 \mathrm{~d}-\mathrm{e}$ ). Young trichomes were commonly curved, resembling the letter "C" or "J" (Figs 1 f, 2 d-e).

Most false branching was formed from 


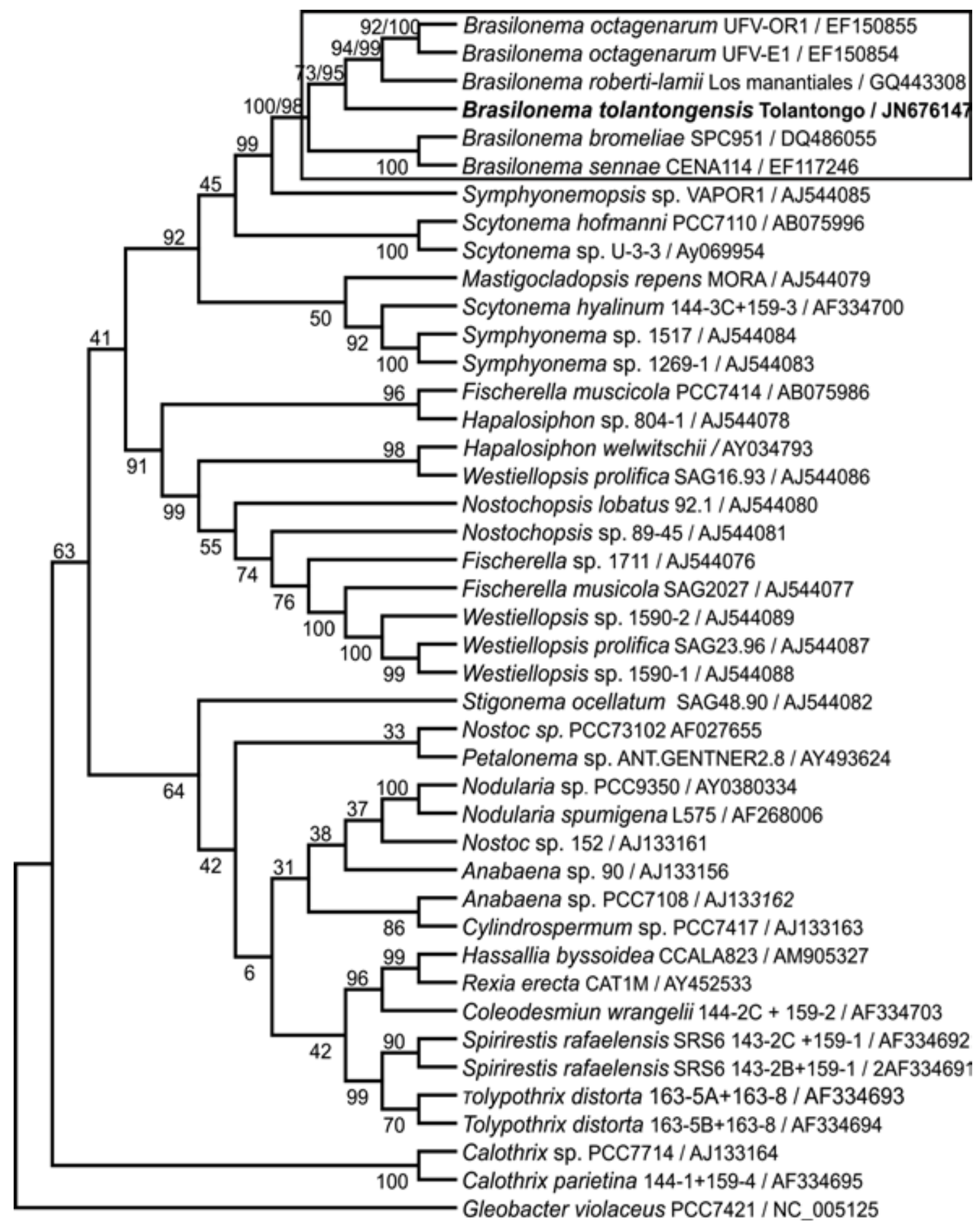

Fig. 3. Phylogenetic tree showing relationships between Brasilonema species and cyanobacteria of the same order (Nostocales), based on sequence analyses of the 16S rRNA gene, with Gloeobacter violaceus as the external functional group.

the rupture of trichomes between two vegetative cells, generally forming two branches (double branching) (Figs $1 \mathrm{~d}, 2 \mathrm{~b}$ ), however single branches were also formed occasionally (single branching). In addition, although less frequently, single branches were formed from hormogonia attached to sheaths (Figs 1 e, $2 \mathrm{f}$ ).

Under natural conditions, heterocytes on trichomes were rarely found. Therefore, observations and photos were made mainly from cultures. Heterocytes were observed as both solitary and intercalary (Figs 1 b, 2 a).

\section{Molecular phylogenetic}

The topology of parsimony and likelihood analyses was similar, particularly with reference 


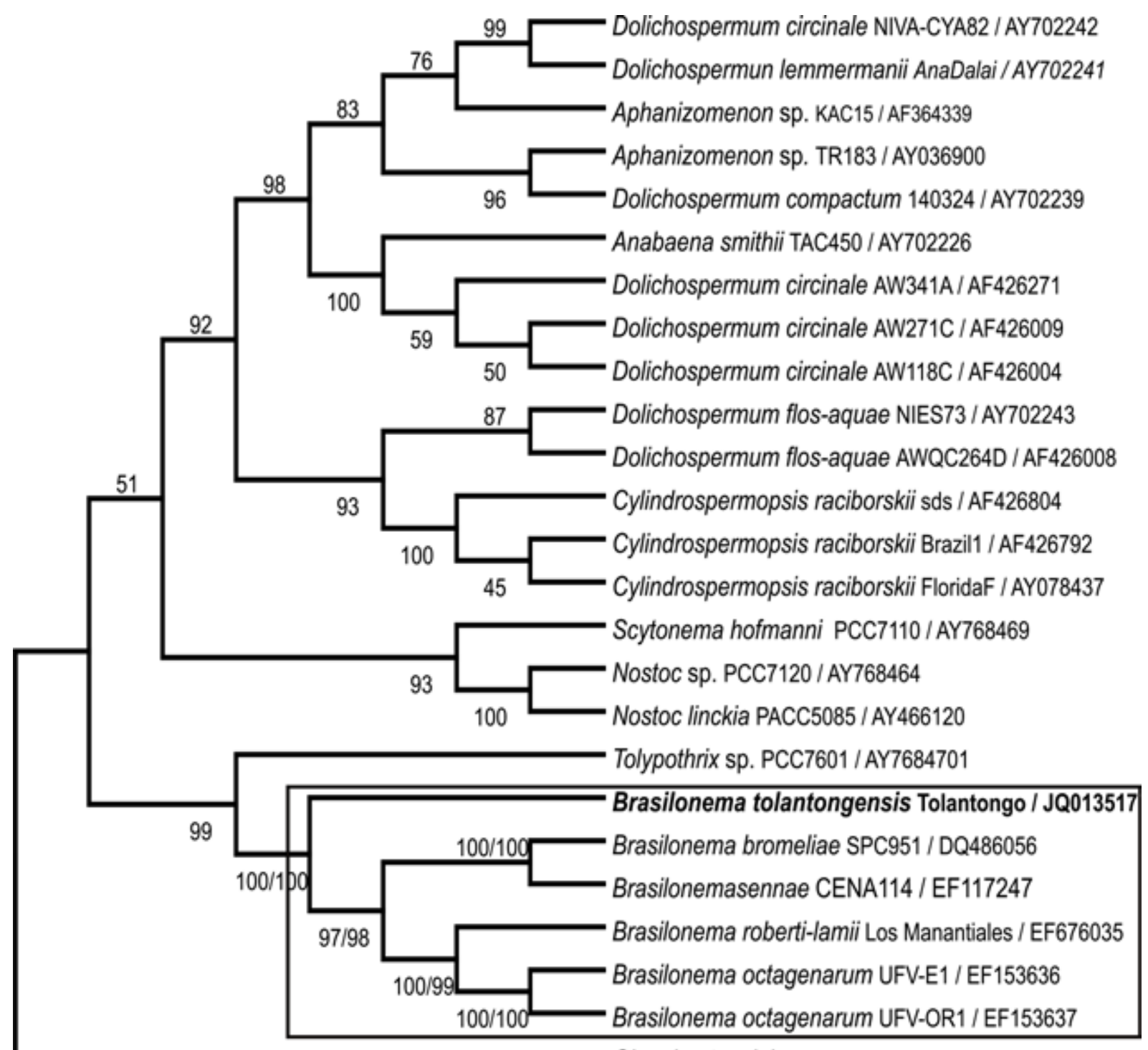

Gloeobacter violaceus PCC7421 / NC_005125

Fig. 4. Phylogenetic tree showing relationships among Brasilonema species and cyanobacteria of the same order (Nostocales), based on sequence analyses of the $c p c \mathrm{BA}-\mathrm{IGS}$ gene, with Gloeobacter violaceus as the external functional group.

to the clade of the genus Brasilonema where the sequence of the strain of Tolantongo is located.

We show the maximum likelihood trees with node support (Figs 3, 4). Node support of the parsimony analysis is presented only for the clade of Brasilonema.

Parsimony analyses using 16S rRNA sequences resulted in two trees where branch length (L) was 1290, consistency index (Ci) was 40 , and retention index (Ri) was 66. The strict consensus tree had $\mathrm{L}=1295, \mathrm{Ci}=40$, and $\mathrm{Ri}=$ 66. On the other hand, sequence analyses with the $c p c$ BA-IGS operon yielded three trees $(\mathrm{L}=913$, $\mathrm{Ci}=63, \mathrm{Ri}=84$ ); where the strict consensus tree had $\mathrm{L}=915, \mathrm{Ci}=63$, and $\mathrm{Ri}=84$.

In both phylogenetic trees, the sequence of species from Tolantongo was grouped next the other species of Brasilonema, with suitable bootstrap values (Figs 3, 4). However, there were some differences between the two markers (Figs 3, 4). In the phylogenetic analyses using 16S rRNA, the sequence studied was included within the clade (Fig. 3), but when the $c p c \mathrm{BA}-$ IGS region was used the sequence of species from Tolantongo fell outside the clade formed by other species of Brasilonema, although they shared a close common ancestor (Fig. 4).

The similarity analysis revealed a $99 \%$ identity between $B$. tolantongensis and $B$. octagenarum (Table 2 ). The next similar strains based on this simple metric were $B$. roberti-lamii (98\%), B. sennae (98\%), B. bromeliae (98\%) 
Table 2. Similarity matrix for 16 strains comparing 43 nucleotide partial sequence of the $16 \mathrm{~S}$ rRNA gene [Strain access numbers: (1) JN676147, (2) EF150855, (3) GQ443308, (4) EF117246, (5) DQ486055, (6) AJ544085, (7) AJ544079, (8) AJ544084, (9) AF334700, (10) AB075996, (11) AF334693, (12)AY493624, (13) AJ544080, (14) AJ133161, (15) AF334695, (16) AY452533].

\begin{tabular}{llllllllllllllll}
\hline & 1 & 2 & 3 & 4 & 5 & 6 & 7 & 8 & 9 & 10 & 11 & 12 & 13 & 14 & 15 \\
\hline 1 Brasilonema tolantongensis & - & & & & & & & & & & & & & & \\
2 Brasilonema octagenarum & 99 & - & & & & & & & & & & & & \\
3 Brasilonema roberti-lamii & 98 & 99 & - & & & & & & & & & & & \\
4 Brasilonema sennae & 98 & 97 & 97 & - & & & & & & & & & & \\
5 Brasilonema bromeliae & 98 & 97 & 97 & 99 & - & & & & & & & & & \\
6 Symphyonemopsis sp. & 97 & 96 & 96 & 96 & 96 & - & & & & & & & & & \\
7 Mastigocladopsis repens & 95 & 95 & 94 & 95 & 95 & 95 & - & & & & & & & \\
8 Symphyonema sp. & 95 & 94 & 94 & 95 & 94 & 94 & 96 & - & & & & & & & \\
9 Scytonema hyalinum & 94 & 95 & 95 & 94 & 94 & 94 & 95 & 97 & - & & & & & & \\
10 Scytonema hofmanni & 93 & 93 & 93 & 93 & 93 & 93 & 93 & 93 & 93 & - & & & & & \\
11 Tolypothrix distorta & 93 & 93 & 92 & 93 & 93 & 94 & 94 & 95 & 93 & 94 & - & & & & \\
12 Petalonema sp. & 93 & 93 & 93 & 93 & 93 & 93 & 94 & 94 & 94 & 93 & 96 & - & & & \\
13 Nostochopsis lobatus & 94 & 92 & 93 & 93 & 93 & 92 & 92 & 94 & 93 & 91 & 94 & 94 & - & & \\
14 Nostoc sp & 92 & 91 & 92 & 92 & 92 & 93 & 93 & 94 & 92 & 92 & 96 & 94 & 92 & - & \\
15 Calothrix parietina & 92 & 92 & 91 & 91 & 91 & 91 & 91 & 91 & 91 & 91 & 91 & 91 & 91 & 91 & - \\
16 Rexia erecta & 90 & 90 & 90 & 90 & 90 & 91 & 91 & 91 & 90 & 89 & 95 & 92 & 91 & 94 & 90 \\
\hline
\end{tabular}

and Symphyonemopsis sp. (97\%). All other representative taxa in Table 2 were at or below $95 \%$ similarity to our strains.

\section{Discussion}

Morphological comparisons between the populations studied and diagnostic characters of Brasilonema (FIORE et al. 2007) indicated that our samples correspond with this genus, including: 1) subaerophytic habitat, with organisms always attached to solid and wet substrates (Fig. 1 a); 2) thalli composed of fasciculated filaments, dark in color ranging from violet to blackish-violet, which is within the variability range for Brasilonema species (Fig. 1a); 3) rigid sheaths, generally colorless, although sometimes yellowish brown; 4) apical cells rounded and closed until hormogonia were released (Figs 1 b, 2 a); 5) cross walls ranging from not constricted to slightly constricted (Figs $1 \mathrm{~b}, 2 \mathrm{a})$; 6) trichomes isopolar but only in adult filaments not undergoing reproduction (Figs $1 \mathrm{~b}$, 2 a); 7) Vacuole - like structures and granulation in the cells (Figs 1 b, 2 a). All these characteristics are found in all Brasilonema species (Table
1) making them critical to defining this genus. Since we identified all of these features in our populations, morphological studies indicate that they do indeed belong to the genus Brasilonema. Some important differences in morphology were also observed in comparison to other species described for Brasilonema including: 1) substrate type: our populations were attached to rock (Fig. 1 a); B. terrestre, B. roberti-lamii are also epilithic species, distinguishing them from the most common epiphytic types such as $B$. bromeliae, $B$. octagenarum, $B$. epidendron, $B$. ornatum, and $B$. sennae, which were found in both sets of conditions and also grew on wet iron substrates (Table 1);2) the fasciculated filaments in the populations from Tolantongo were creeping, a characteristic shared with $B$. octagenarum and $B$. ornatum, and differing from $B$. bromeliae, $B$, sennae, $B$. roberti-lamii, $B$. epidendron, and $B$. terrestre which have erect fascicles (Table 1). In the generic diagnosis, creeping fascicles are not included (FIORE et al. 2007), indicating that the previously described characteristics do not reflect the variety of species regarding the arrangement of fascicles; 3 ) sheath morphology revealed three characteristics (Table 1): a) thin, non-lamellated 
sheaths were found in our populations (Figs 1 $\mathrm{b}, 2 \mathrm{a}$ ), in B. epidendron and B. terrestre; b) thin sheaths with slightly late lamellation (only in older filaments) were observed in B. octagenarum, $B$. sennae, and probably also in B. bromeliae (FIORE et al. 2007); c) thick, lamellated sheaths were observed in B. roberti-lamii and B. ornatum; 4) filaments and trichomes were wider in strain from Tolantongo than in other species. Although filament measurements overlapped with those of B. octagenarum, B. sennae, and B. ornatum, and trichome measurements overlapped with those of B. bromeliae, B. octagenarum, B. sennae, and $B$. ornatum, in both cases the populations from Tolantongo has the largest dimensions (Table 1); 5) hormogonia were wider than trichomes (Figs $1 \mathrm{c}$, $2 \mathrm{c}$ ); to date only the species from Tolantongo has this feature, since it remains unreported for other species (however, hormogonia measurements are not always included in their descriptions); 6) hormogonia and young trichomes had asymmetric growth (Figs 1 f, 2 d); although, we found asymmetric growth described in the observations or descriptions of B. octagenarum and B. robertilamii (Aguiar et al. 2008; Rodarte et al., unpubl.); it seems that in these species asymmetric growth occurred only during early stages of hormogonia growth, compared to our populations where it continued until young trichomes were formed (Figs 1 f, 2 e); 7) one or both apical cells were attenuated in hormogonia and young trichomes characteristic of this species (Figs $1 \mathrm{f}, 2 \mathrm{~d}$ ).

Morphological analyses of the species from Brasilonema showed that our populations had important differences, indicating the discovery of a new species.

In populations from Tolantongo, adult trichomes were generally isopolar, with the exception of those forming hormogonia; these structure were always wider than trichomes and generally grew only on one end (Figs 1 c, 2 c); giving them a heteropolar appearance.

Young trichomes had a highly characteristic shape, resembling the letter " $\mathrm{C}$ " or " $\mathrm{J}$ ", and its early development phases were heteropolar as a result of the asymmetric germination of hormogonia (Figs $1 \mathrm{f}, 2 \mathrm{~d}-\mathrm{e}$ ). The germination of hormogonia generally began with the formation of one or two heterocytes; the bond between these was a fragmentation point, which resulted in two hormogonia with basal heterocytes (observations in culture). Later, only the meristematic cells began dividing from one end (that opposite of the basal heterocyte), and generally this end became attenuated (Figs 1 f, 2 d-e).

KomÁREK \& ANAGNOSTIDIs (1989) showed that development of hormogonia is isopolar in the Scytonemataceae family. This isopolarity was defined by the symmetrical germination of hormogonia on both ends. However, germination of hormogonia was asymmetric in the populations we studied. When we consulted the descriptions, observations and images of the species of Brasilonema (Fiore et al. 2007; Aguiar et al. 2008; SANT' ANNA et al. 2011), we found that some species, such as B. bromeliae and B. octagenarum, showed hormogonia with basal heterocytes, and the end opposite to the heterocyte was slightly attenuated (Fiore et al. 2007; Aguiar et al. 2008), such as we observed in the strains from Tolantongo. The same observation was made in B. roberti-lamii, which RODARTE et al. (unpubl.) interpreted as early asymmetric growth; $B$. terrestre, B. epidendron and B. ornatum appeared to have symmetrical hormogonia growth during development (SANT' ANNA et al. 2011). In future studies of species from this genus, it will be important to observe how hormogonia develops. Perhaps previously described species should be reevaluated since most descriptions fail to include analysis of this characteristic. A more detailed investigation into the life cycle of all Brasilonema species could demonstrate that during the early stages of hormogonia and young trichomes the development may always be asymmetrical.

When describing hormogonial development in our populations, "symmetry" is a better term than "polarity" due to that at the beginning of hormogonia germination are divided the meristematic cells of only one of their ends. This asymmetric division causes the heteropolarity of the young trichomes. Although isopolarity was reestablished in mature trichomes, they maintained their asymmetry, in the hormogonia formation that happens only at one end of trichomes.

In light of the above, "polarity" should be applied to only the terminal parts of trichomes. They should be considered isopolar when, they have similar ends and heteropolar when the ends are different, i.e. one with a heterocyte, and the other attenuated or wide. On the other hand, "symmetry" should be applied to describe the development of hormogonia. They should be considered symmetrical if both halves grow exactly the same manner, i.e. hormogonia divided in two equal portions, and asymmetrical if both 
halves grow differently, i.e. one portion begins to grow before the other, or one end becomes attenuated while the other does not.

All Brasilonema species have intercalar heterocytes on mature trichomes. However, basal heterocytes on hormogonia were also reported in almost all Brasilonema species. For this reason, it is very important that features such as the presence of intercalary heterocytes and the polarity of trichomes be associated with the ontogenetic development (life cycle) of the species.

A main difference between Brasilonema species, including our populations and the species of other genera of Scytonemataceae, is the shape acquired by young trichomes (FIORE et al. 2007; Aguiar et al. 2008; SANT' AnNa et al. 2011). Young trichomes were curved, resembling the letter "C" or "J"(Figs $1 \mathrm{f}, 2 \mathrm{~d}$, e). This trichome shape apparently contributes to thallus formation because it contributes to maintaining the fascicles of the filaments.

According to FIORE et al. (2007), Brasilonema shows two types of branching that we also observed in the populations from Tolantongo: 1) a typical branching formation that is characteristic of the Scytonemataceae family, which forms from the folding of trichome and the interruptions in the trichome between vegetative cells folded, resulting in two parallel branches (KomÁreK \& Anagnostidis 1989; Korelusová 2008); 2) a second type of branching, also due to an interruption in the trichome between vegetative cells, but in the absence of folding, where only one branch is formed (Figs $1 \mathrm{~d}, 2 \mathrm{~b}$ ). This second type of branching is named as Tolypothrix-type by FIORE et al 2007. However, according to KomÁrek \& ANAGNOSTIDIS (1989), branching of the Tolypothrix-type is formed by an interruption in the trichome between a heterocyte and a vegetative cell, resulting in a single branch.

Regardless of the fact that both branching patterns result in a single branch, these two types of branching patterns (Brasilonema and Tolypothrix) are clearly different at the ontogenetic level. Furthermore we suggest that the previously identified branching pattern in Brasilonema (Tolypothrix-type) is incorrect. This observation should not be ignored because Brasilonema and Tolypothrix Kutzing ex Bornet et Flahault belong to different families that are defined by their type of branching. In Scytonemataceae, branching is between vegetative cells (Figs $1 \mathrm{~d}, 2 \mathrm{~b}$ ), while in the Tolypothrix family, Microchaetaceae
LEMMERMANN, branching is between heterocytes and vegetative cells (KOMÁREK \& ANAGNOSTIDIS 1989).

We observed a third type of false branching in our populations: branches forming when a hormogonium attaches to a filament sheath and begin to germinate (Figs $1 \mathrm{e}, 2 \mathrm{f}$ ); this branching type was described earlier by PANDEY (1974) in Scytonematopsis. It appears that this type of branching is also found in other species of $B$ rasilonema, including $B$. sennae and B. terrestre (SANT' ANNA et al. 2011). In images of $B$. robertilamii (SANT' ANNA et al. 2011), there is a branch with a basal heterocyte but was interpreted as tolypotrichoid branching. We consider that this corresponds to the third type of branching, where a hormogonium with a basal heterocyte is attached to the sheath of another filament, and begins to grow by forming a branch. This type of branching was observed in populations of $B$. roberti-lamii in Los Manantiales, in the state of Morelos, México (RoDARTE et al., unpubl.).

Molecular phylogenetics (Figs 3, 4) and the similarity analyses (Table 2) were consistent with morphological results and support the hypothesis that the species from Tolantongo belongs to Brasilonema, and that it is in fact a new species. In phylogenetic analyses using both $16 \mathrm{~S}$ rRNA gene and $c p c \mathrm{BA}-\mathrm{IGS}$ sequences, The Tolantongo's strain had a close common ancestor with Brasilonema species. The differences observed with these two molecular markers (Figs 3,4) can be explained by the nature of each one: the $16 \mathrm{~S}$ rRNA gene is more conserved and it is the most widely accepted for phylogenetic studies which establish relationships between genera or superior taxa (КомÁReK 2010); whereas the $c p c \mathrm{BA}-\mathrm{IGS}$ region is chosen as a potentially highly variable one, useful for identifying cyanobacteria at the species level, in strains or populations (NEILAN et al. 1995). Therefore, phylogeny using $16 \mathrm{~S}$ rRNA sequence demonstrated that our species belongs to Brasilonema, and phylogeny with the $c p c \mathrm{BA}-$ IGS sequence demonstrated that it is different from previously described species of this genus, showing it to be a new species.

In conclusion, based on morphological, and molecular analyses we consider that the strain from Tolantongo is a new species, which we name Brasilonema tolantongensis based on the name of the site where it was found. 


\section{Acknowledgements}

The authors would like to thank Dr. Michele Gold for reviewing the English and their comments to improve the paper, Dr. Esther Berrendero and Biol. Guadalupe Bibriesca for their collaboration in the molecular aspects of this study; Biol. Oscar López Sandoval for his field work contribution; Dr. Helga Ochoterena for her invaluable assistance with phylogenetic analysis; PAPIIT for supporting project No. IN207709; and to The Willi Henning Society for making the software program TNT freely available. Itzel Becerra-Absalón is grateful to the Posgrado en Ciencias Biológicas, UNAM for the training and support received during $\mathrm{PhD}$ studies and CONACyT for her doctoral scholarship.

\section{References}

Abed, R.M.M.; García-Pichel, F. \& HernándeZMARINÉ, M. (2002): Polyphasic characterization of benthic, moderately halophilic, moderately thermophilic cyanobacteria with very thin trichomes and the proposal of Halomicronema excentricum gen. nov. sp. nov. - Arch. Microbial. 177: 361-70.

Aguiar, R.; Fiore, M. F.; Franco, M. W.; Ventrella, M. C.; Lorenzina, A.; Vanetti, C. \& Alfenas, A. C. (2008): A novel epiphytic cyanobacterial species from the genus Brasilonema causing damage to Eucalyptus leaves. - J. Phycol. 44: 1322-1334.

Allen, M.B. (1968): Simple conditions for growth of unicellular blue-green algae on plates. $-\mathrm{J}$. Phycol. 4: 1-4.

Bourrelly, P. \& Manguin, E. (1952): Algues d'eau douce de la Guadaloupe et dependances recueillies par la Mission P. Allorge en 1936, Societé D'Education d'Enseignement Supérieur, Paris.

Casamatta, D.A.; Gomez, S.R \& Johansen, J.R. (2006): Rexia erecta gen.et sp. nov. and Capsosira lowei sp. nov., two newly described cyanobacterial taxa from the Great Smoky Mountains National Park (USA). - Hydrobiologia 561: 13-26.

Castenholz, R.W. (2001): Oxygenic photosynthetic bacteria. - In: Boone, D.R. \& CAnstenholz, R.W. (eds): Bergey's Manual of Systematic Bacteriology, Vol. $12^{\text {nd }}$ ed. - pp. 473 - 600, Springer-Verlag, New York.

Fiore, M.F.; Sant'Anna, C.L.; Azevedo, M.T,P.; JomÁreK, J.; Kaštovský, J.; SuleK, J. \& Lorenzi, A.S. (2007): The cyanobacterial genus Brasilonema, gen. nov., a molecular and phenotypic evaluation. - J. Phycol. 43: 789-98.

Flechtner, V.R.; Boyer, S.L.; Johansen, J.R. \& DeNoble, M.L. (2002): Spirirestis rafaelensis gen. et sp. nov. (Cyanophyceae), a new cyanobacterial genus from arid soils. - Nova Hedwigia 74: 1-24.

Goloboff, P.A.; Farris, J. S. \& Nixon, K. C. (2008): TNT, a free program for phylogenetic analysis. - Cladistics 24: 774-786.

Gugger, M.; Lyra, C.; Henriksen, A.; Couté, A.; Humbert, J.F. \& Sivone, K. (2002): Phylogenetic comparison of the cyanobacterial genera Anabaena and Aphanizomenon. - Int. J. Syst. Evol. Microbiol. 52: 1-14.

Gugger, M. \& Hoffmann, L. (2004): Polyphyly of true branching cyanobacteria (Stigonematales). Int. J. Syst. Evol. Microbiol. 54: 349-357.

Hall, T.A. (1999): Bioedit: A user-friendly biological sequence alignement editor and analysis program for Windows 95/98/NT. - Nucl. Acids. Symp. Ser. 41: 95-98.

Higgins, D.; Thompson, J.; Gibson, T.; Thompson, J.D.; Higgins, D.G. \& Gibson, T.J. (1994): Clustal W: improving the sensitivity of progressive multiple sequence alignment through sequence weighting, position-specific gap penalties and weight matrix choice. - Nucleic Acids Res. 22: 4673-4680.

HrouzeK, P.; Ventura, S.; LukeŠová, A.; Mugnai, M.A.; Turicchia, S. \& KomÁrek, J. (2005): Diversity of soil Nostoc strains: phylogenetic and morphological variability. - Algological Studies (Cyanobact. Res. 6) 117: 251-264.

KomÁReK, J. (1989): Studies on the Cyanophytes of Cuba 7-9. - Folia Geobotanica Phytotaxonomica 24: 171-206.

KOMÁREK, J. (2003a): Problem of the taxonomic category species in cyanobacteria. - Algological Studies (Cyanobact. Res. 4) 109: 247-345.

KomÁReK, J. (2003b): Two Camptylonemopsis species (Cyanoprokaryotes) from Mata Atlántica in coastal Brazil. - Preslia 75: 223-232.

KomÁreK, J. (2006): Cyanobacterial taxonomy: Current Problems and prospects for the integration of traditional and molecular approaches, - Algae 21: 349-375.

KomÁReK, J. (2010): Recent changes (2008) in cyanobacteria taxonomy based on a combination of molecular background with phenotype and ecological consequences (genus and species concept). - Hydrobiologia 639: 245-259.

KomÁReK, J. (2011): Introduction to the $18^{\text {th }}$ IAC Symposium in České Budějovice 2010, Czech Republic. Some current problems of modern cyanobacterial taxonomy. - Fottea 11:1-7.

KomáreK, J. \& Anagnostidis, K. (1989): Modern approach to the classification system of cyanophytes 4 - Nostocales. - Algological Studies 56: 247-345.

KorelusovÁ, J. (2008): Phylogeny of heterocytous Cyanobacteria (Nostocales and Stigonematales. - 33 pp., University of South Bohemia in Ceske 
Budejovice Faculty of Science.

Montejano G.; Rodarte, B.; LeÓn-Tejera, H.; Osorio, K.; Alba-Lois, L.; Becerra, I. \& Segal, C. (2010): Diversity of species of Scytonemataceae (Nostocales, Cyanoprokaryota) from different biotopes in Central Mexico. - In KoMÁreK, J.; Hauer, T. \& KaštovskÝ, J. (eds): Book of abstracts, $18^{\text {th }}$ symposium of the International Association for Cyanophyta Research. -27 pp., Institute of Botany the Academy of Science of the Czech Republic, Zámek 1, Prühonice, Czech Republic.

Neilan, B.; Jacobs, D. \& Goodman, E.A. (1995): Genetic Diversity and Phylogeny of Toxic Cyanobacteria Determined by DNA Polymorphisms within the Phycocyanin Locus. - Appl. Environm. Microbiol. 61: 3875-3883

Neilan, B.A.; Jacobs, D.; Del Dot, T.; Blackall, L.L.; Hawkins, P.R.; Cox, P.T. \& Goodman, A.E. (1997): rRNA sequences and evolutionary relationships among toxic and nontoxic cyanobacteria of the genus Microcystis. - Int. J. Syst. Bacteriol. 47: 693-697.

Nixon, K.C. (2002): Winclada Ver. 1.00.08, Published by the autor, Ithaca, NY.

Nübel, U.; García-Pichel, F. \& Muyzer, G. (1997): PCR primers to amplify $16 \mathrm{~S}$ rRNA genes from cyanobacteria. - Appl. Environ. Microbiol. 63: 3327-3332.

Palinska, K.A.; Thomasius, C.F.; Marquardt, J. \& Golubić, S. (2006): Phylogenetic evaluation of cyanobacteria preserved as historic herbarium exsiccate. - Int. J. Syst. Evol. Microbiol. 56: 2253-2263.

PANDEY, D.C. (1974): Observations on Reproduction in Scytonematopsis ghazipurensis Pandey \& Mitra. - Hydrobiologia 44: 365-367.

Rajaniemi, P.; Komárek, J.; Hoffmann, L.; Hrouzek, P.; KaštovskÁ, K. \& Sivonen, K. (2005): Taxonomic consequences from the combined molecular and phenotype evaluation of selected Anabaena and Aphanizomenon strains. Algological Studies 117: 371-91.

Sant'Anna, C.L.; Azevedo, M.T.P.; Fiore, M.F.; LorenZi, A.S.; KaštovskÝ, J. \& KomÁreK, J. (2011): Subgeneric diversity of Brasilonema (Cyanobacteria, Scytonemataceae). - Revista Brasil. Bot. 34: 51-62.

Tamura, K.; Peterson, D.; Peterson, N.; Stecher, G.; NeI, M \& Kumar, S. (2011): MEGA5: Molecular Evolutionary Genetics Analysis using Maximum Likelihood, Evolutionary Distance and Maximum Parsimony Methods. Mol. Biol. Evol. 28: 2731-2739.

VACCARINO, M.A. \& JohANSEN, J.R. (2011): Scytonematopsis contorta sp. nov. A new species from the Hawaiian Islands. - Fottea. 11: 149-161.
Willame, R.; Boutte, C.; Grubisic, S.; Wilmotte, A.; KomÁrek, J. \& Hoffman. L. (2006): Morphological and molecular characterization of planktonic cyanobacteria from Belgium and Luxembourg. - J. Phycol. 42: 1312 - 1332.

(C) Czech Phycological Society (2013)

Received February 29, 2012

Accepted October 10, 2012 